\title{
Primary production dynamics in seagrass beds of Mississippi Sound: the contributions of seagrass, epiphytic algae, sand microflora, and phytoplankton
}

\author{
Cynthia A. Moncreiff, Michael J. Sullivan, Andreas E. Daehnick
}

Department of Biological Sciences, PO Drawer GY, Mississippi State University, Mississippi State, Mississippi 39762, USA

\begin{abstract}
Primary production rates of 4 autotrophic components in Halodule wrightii Aschers. beds off Horn Island in Mississippi Sound (USA) were measured over an annual cycle. Hourly production rates varied from as little as $0.9 \mathrm{mg} \mathrm{C} \mathrm{m}^{-2}$ for $H$. wrightii leaves in winter to as high as $1143 \mathrm{mg} \mathrm{C} \mathrm{m}^{-2}$ for epiphytic algae during summer. Stepwise multiple regression showed that only $15 \%$ of the variation in hourly epiphytic algal production could be related to a single environmental variable (i.e. light energy). Variations in hourly production rates for the other productivity components were best explained by light energy, water temperature, tidal range and blade density; $\mathrm{R}^{2}$ for these regressions was 0.66 and 0.80 for phytoplankton and seagrass blades respectively. The epiphytic algal assemblage on $H$. wrightii leaves was dominated by the red alga Acrochaetium flexuosum Vickers and 12 taxa of araphid, monoraphid and biraphid diatoms. Phytoplankton over the beds were virtually all centric diatoms, whereas the microflora associated with the sandy sediments in which $H$. wrightii was rooted was dominated by small pennate diatoms. Annual production rates $\left(\mathrm{g} \mathrm{C} \mathrm{m}^{-2}\right)$ were estimated as follows: epiphytic algae (905), phytoplankton (468), sand microflora (339) and Halodule wrightii (256). System production was dominated by the microalgae, with the contribution of $H$. wrightii blades being only $13 \%$ of the total. Epiphytic algae were the single most important productivity component, being responsible for 46 and $60 \%$ of total system and benthic production respectively. The high standing crops and production rates of the epiphytic and benthic microalgae are of interest in that recent studies have indicated these algae can be the principal source of organic matter in seagrass food webs.
\end{abstract}

\section{INTRODUCTION}

Seagrass beds constitute extremely productive ecosystems in shallow coastal waters. Their complexity in both structure and function is due to the great diversity and abundance of organisms present. Attached to the seagrass leaf blades is a diverse and highly productive epiphytic assemblage, comprised mainly of microscopic algae; this assemblage is dominated by various species of diatoms and red, brown, green and blue-green algae (Humm 1964, Ballantine \& Humm 1975, Sullivan 1979, Thursby \& Davis 1984). Sediments beneath and adjacent to the seagrass beds are carpeted with a microfloral community populated primarily by species of small pennate diatoms.

In addition to acting as substrate for epiphytic algae, seagrasses function as habitat for many invertebrate and small vertebrate marine organisms. Resident fauna associated with seagrass beds include copepods, amphipods, isopods, shrimp, crabs, other small crustaceans, gastropods, nematodes, polychaetes, echinoderms and small fish (Kitting 1984, Kitting et al. 1984, Morgan \& Kitting 1984). Recent research indicates that the epiphytic algal assemblage may be the primary food source within this community, as opposed to the seagrasses and the detrital material they generate (Fry et al. 1982, 1987, Fry 1984, Kitting et al. 1984, Nichols et al. 1985, Gleason 1986, Dauby 1989)

Epiphytic algae may contribute significantly to both primary production and autotrophic biomass in seagrass beds. Reported productivity values for seagrass epiphytes range from 8 to $56 \%$ of the total leaf plus epiphyte production (Borum et al. 1984, Morgan \& Kitting 1984). Biomass can range from as little as $1 \%$ to a maximum of $68 \%$ of the leaf plus epiphyte total (Borum \& Wium-Andersen 1980, Morgan \& Kitting 
1984). The latter values in both cases are from Halodule wrightii Aschers. beds in a southern Texas, USA, bay where seagrass epiphyte contributions to primary production and to biomass averaged $50 \%$ of the total. Preliminary research for the present study in $H$. wrightii beds showed that on a dry weight basis, the standing crop of algal epiphytes can equal or exceed that of the seagrass blades.

The major objective of the present study was to quantify the production of organic matter by all autotrophic components of representative seagrass beds in Mississippi Sound (USA) over an annual cycle, and to determine which components were the dominant contributors to primary production and thus potentially important to the base of local food webs. Such measurements do not exist for the most northerly temperate seagrass beds in the Gulf of Mexico. A secondary objective was to compare the relative importance of epiphyte production to total benthic and system production in our beds with those of other beds on a worldwide basis. Such data are important because stable isotope studies in shallow water environments are increasingly pointing out the importance of benthic microalgal rather than macrophytic carbon to higher trophic levels (e.g. Kitting et al. 1984, Peterson \& Howarth 1987, Sullivan \& Moncreiff 1990, Hamilton et al. 1992).

\section{MATERIALS AND METHODS}

Study area. Horn Island is one of the 5 islands comprising the barrier island chain off the Mississippi coast, extending roughly $22 \mathrm{~km}$ from Dog Keys Pass at

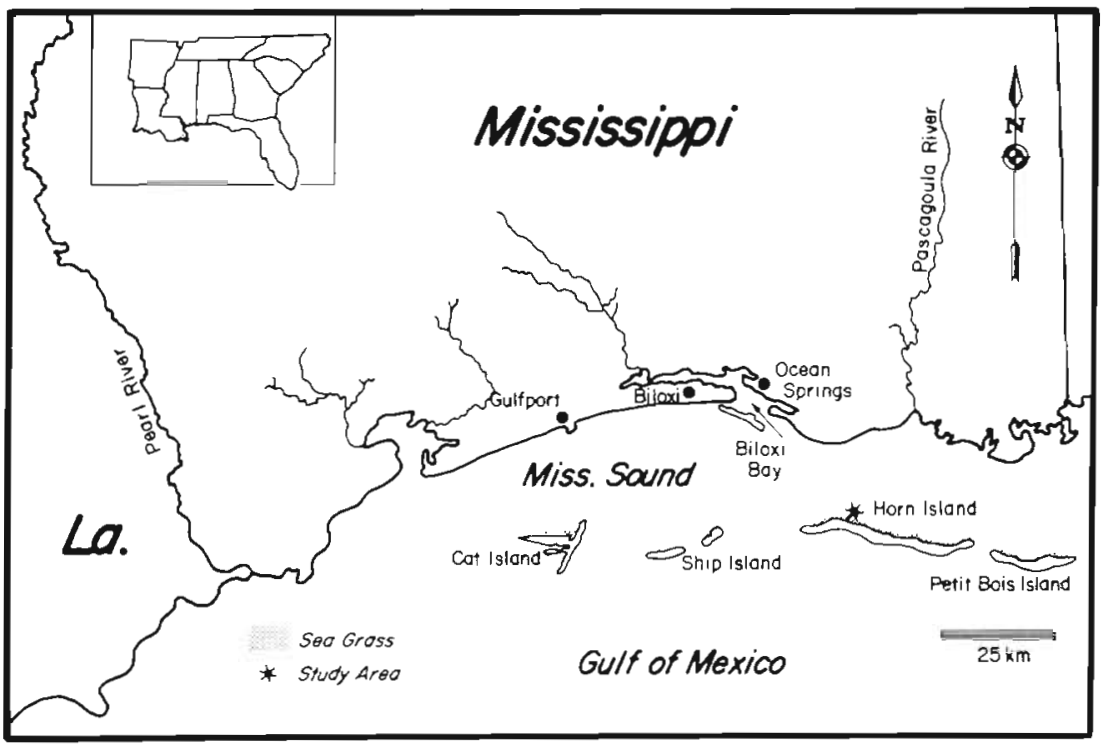

Fig. 1. Map of Mississippi Sound (USA) and the northern Gulf of Mexico indicating location of the study area its western extremity ( $N 30^{\circ} 15^{\prime}, W 88^{\circ} 45^{\prime}$ ) to Horn

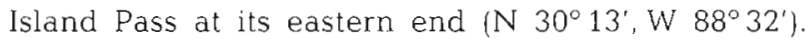
Freshwater influences are a function of discharge rates and prevailing winds; Biloxi Back Bay and the Biloxi and Pascagoula Rivers can potentially affect the area. Upland drainage from the island proper is negligible. Astronomical tidal range is $0.6 \mathrm{~m}$; the effects of wind on local hydrodynamics generally overrides this and tends to determine local water depth and surface level fluctuations. During the course of this study, the shallow water $(<2 \mathrm{~m})$ sand flats on the side of the island bordering Mississippi Sound were populated exclusively by beds of Halodule wrightii.

Sampling strategy. Seagrass beds were sampled along the western end of Horn Island (Fig. 1). These beds have proved to be extremely persistent, surviving both extended periods of low salinity and strong storms, including hurricanes. Sampling was attempted on a monthly basis, beginning in June 1989 and concluding in June 1990. Adverse weather conditions and equipment breakdown prohibited access to the study site during months for which no data are presented. A total of 11 measurements were made. Three adjacent beds were selected for productivity measurements during each month samples were collected; a different set of beds was used on consecutive trips. Beds were selected on the basis of visual estimates of size, blade density, and degree of epiphytization, relative to all beds inspected in the area.

Seagrass and epiphyte biomass measurements. Above-ground live biomass for each of the 3 Halodule wrightii beds was estimated by the method of Morgan \& Kitting (1984). Two $10 \times 10 \mathrm{~cm}$ quadrats were randomly selected in each bed. All seagrass blades from each quadrat were clipped at the sediment surface. Samples were stored on ice for transport from the study area to the laboratory. Upon return to the laboratory, the leaves were gently rinsed with distilled water for salt removal (epiphyte removal was negligible) and dried at $60^{\circ} \mathrm{C}$ to a constant weight, yielding a total combined dry weight for seagrass leaves and their associated epiphytes on an areal basis. Ten or more blades were selected at random; the epiphytes were carefully scraped from these blades and the dry weights of epiphytes and seagrass blades determined separately. Their ratio was used to estimate the $g$ dry wt $\mathrm{m}^{-2}$ contribution of the seagrass and epiphyte components to total biomass. 
Primary production measurements. A total of 6 incubations were carried out in each of the 3 beds for the sand microflora (see Daehnick et al. 1992 for details) and the seagrass blades and epiphytes, while 3 incubations were carried out per bed for the phytoplankton. All samples received $5 \mu \mathrm{Ci} \mathrm{NaH}{ }^{14} \mathrm{CO}_{3}$ and were incubated in situ by placing them back in the seagrass bed under ambient conditions of light and temperature for $3 \mathrm{~h}$. Inactive ${ }^{14} \mathrm{C}$ uptake was estimated via addition of $10^{-5} \mathrm{M}$ dichlorophenyl dimethyl urea (DCMU), dissolved in distilled water, to 1 sample for each autotrophic component per bed. DCMU is a herbicide which inhibits the operation of Photosystem II and active carbon uptake, thus generating a 'blank' for determination of absolute active uptake of ${ }^{14} \mathrm{C}$ (Legendre et al. 1983). Microbial activity is included in this 'blank'. Values for the DCMU treatments were subtracted from those for isotope only when calculating uptake rates. Uptake of ${ }^{14} \mathrm{C}$ at the end of each incubation period was stopped by the addition of buffered $4 \%$ formalin. Samples were then transported to the laboratory on ice.

Upon return to the laboratory, samples were held at $4{ }^{\circ} \mathrm{C}$ until processing (within $<1$ wk after collection). Pertinent details of sample processing methods are summarized by component. Prepared samples were counted using a Beckman LS 3801 liquid scintillation counter programmed for 'wide-window' counting (color and chemical quench correction). Counts (dpm) were converted to uptake rates, as described for each component. A factor of 1.064 was employed to correct for differential uptake of ${ }^{14} \mathrm{C}$. Since unfiltered Mississippi Sound seawater was used in all incubations, phytoplankton production was subtracted from the total measured uptake for the other autotrophic components.

Seagrass blades and epiphytes. Productivity estimates combined techniques of van Raalte et al. (1974), Penhale (1977), Morgan \& Kitting (1984) and Jensen \& Gibson (1986). Primary production as ${ }^{14} \mathrm{C}$ uptake was measured simultaneously for both seagrass leaves and their epiphytes. Individual leaves were clipped near their bases and incubated in clear $70 \mathrm{ml}$ glass test tubes. The number of blades incubated per jar and their degree of epiphytization were chosen on each sampling date so as to approximate existing conditions in the beds (Morgan \& Kitting 1984). Morgan \& Kitting (1984) found that clipped Halodule wrightii blades continued to grow for a week in the lab and concluded that clipping effects on production were negligible for short incubation times

Seagrass leaves with attached epiphytes were removed from the test tubes in the laboratory and washed with $10 \% \mathrm{HCl}$ onto $0.45 \mu \mathrm{m}$ nitrocellulose filters to remove unincorporated adsorbed label and to trap loosely attached epiphytes. Seagrass blades were removed from the filtration apparatus and the epiphytes scraped of the blades with a dulled dissecting knife; the epiphytic material thus obtained was rinsed onto the filters containing the loosely attached epiphytes, combining them for the epiphyte sample. Penhale (1977) and Morgan \& Kitting (1984) reported high removal efficiencies (>90\%) using scraping techniques for Zostera marina L. and Halodule wrightii epiphytes respectively. Microscopic examination of our similarly treated unlabelled seagrass blades and epiphytes indicated similar efficiencies of removal. Epiphyte and blade samples were subjected to cold concentrated $\mathrm{HNO}_{3}$ digestion for a minimum of $48 \mathrm{~h}$ to homogenize the labelled organic matter, using a modification of the technique outlined by van Raalte et al. (1974). Calcareous material was virtually absent from all samples; no calcareous red algae were encountered as epiphytic species during the course of the study. Bryozoans, when present, were dissolved during the $\mathrm{HNO}_{3}$ digestion.

Productivity rates were calculated using 2 approaches: (1) $\mathrm{mg} \mathrm{C} \mathrm{m} \mathrm{C}^{-2} \mathrm{~h}^{-1}$, on the basis of average seagrass blade densities in the $100 \mathrm{~cm}^{2}$ plots from each bed, for both the seagrass blades and the epiphytes and (2) $\mathrm{mg} \mathrm{C} \mathrm{g}^{-1}$ dry wt $\mathrm{h}^{-1}$ for the seagrass blades and epiphytes, respectively. Both employed modifications of the formulas of Penhale (1977). The latter rates were used to estimate areal rates for primary production (mg C m $\mathrm{m}^{-2} \mathrm{~h}^{-1}$ ) by multiplying the calculated weight specific hourly rates by the biomass determinations for blades and for epiphytes for each bed (Jensen \& Gibson 1986).

Phytoplankton. Water column algal production was estimated via a modification of Strickland \& Parsons (1972) classic technique. Water samples, collected from immediately above the seagrass beds, were incubated in situ in clear $300 \mathrm{ml}$ borosilicate glass BOD bottles. Samples were drawn down onto $0.45 \mu \mathrm{m}$ nitrocellulose filters and washed with $10 \% \mathrm{HCl}$ to remove unincorporated adsorbed label. The filters were allowed to dry completely prior to addition of an LSC cocktail for counting. Counts (dpm) were converted to uptake rates for phytoplankton and expressed as $\mathrm{mg} \mathrm{C} \mathrm{m}^{-3}$ $\mathrm{h}^{-1}$. As stated previously, these rates were used to generate correction factors to account for ${ }^{14} \mathrm{C}$ uptake by phytoplankton present in the incubation chambers for seagrass blades and epiphytes and the sand microflora.

Microalgal floristics. On all collection dates, samples were procured for taxonomic examination to determine the dominant algal taxa constituting each productivity component. Phytoplankton were sampled using a $26 \mu \mathrm{m}$ mesh Nitex plankton net towed by hand over the seagrass beds for 2 min; care was taken to 
keep the net below the surface yet sufficiently above the seagrass beds to avoid the introduction of loosely attached epiphytes from the seagrass beds themselves. Epiphyte samples were obtained as subsamples of the material clipped from the beds for the ${ }^{14} \mathrm{C}$ incubations.

Environmental factors. Environmental factors considered potentially important in regulating seagrass and epiphyte production were monitored during in situ experiments. These included photosynthetically active radiation (PAR) reaching the leaves and epiphytes, water temperature, salinity, sea state, turbidity, and current speed. PAR was measured using a LiCor Quantum Radiometer Photometer Model No. LI-185B (Li-Cor, Inc., Lincoln, NE, USA), equipped with an underwater sensor. Measurements were made both at the surface (full sunlight) and immediately above the seagrass bed canopy; the latter measurement was used in all regression analyses. Water temperature within the seagrass beds was measured using a YSI Model 33 CST meter (Yellow Springs Instrument Co., Yellow Springs, $\mathrm{OH}$, USA). Salinity was determined using a refractometer. Sea state was visually assessed and recorded at the beginning and end of each trip, with any major changes and their time of occurrence being noted. Turbidity was measured as Secchi depth and was recorded to the nearest $5 \mathrm{~cm}$. Current speed was measured using a General Oceanics Model 2030 digital current meter, equipped with a low-speed rotor (General Oceanics, Inc., Miami, FL, USA). Additionally, predicted tidal range was recorded for each sampling date from published tide tables.

Data analysis. Hourly production rates for each productivity component were related to selected environmental factors and biomass via stepwise multiple regression analysis (SAS Institute Inc. 1988). The stepwise procedure used here will cease adding variables to the regression equation when none of the remaining variables has as $F$-value $\geq 4$.0. Independent variables employed in the models included sampling date (a temporal indicator), light energy (PAR), water temperature, current speed, tidal range, salinity and seagrass blade density.

\section{RESULTS}

\section{Floristics}

Seagrasses were viable over an annual cycle at the study site, even during their temporary burial by shifting sands in March 1990. Degree of epiphytization of Halodule wrightii blades changed dramatically from one month to the next, with the most extensive development being observed in July 1989 and January 1990. Degree of development of the sand microflora also varied greatly, with a thick 'crust' of microflora observed within the seagrass beds on some dates. Occasionally, a distinct golden-brown color was apparent on the sediment surface beneath the seagrass blades. Phytoplankton populations appeared to be well-developed throughout the study but no attempt was made to quantitate their abundance.

The most remarkable aspects of the non-diatom algal flora epiphytic on Halodule wrightii (Table 1) were the paucity of species and the virtual absence of green and blue-green algal epiphytes. A very occasional blue-green algal filament was encountered, but their abundance was so insignificant they were not included in Table 1. The red alga Acrochaetium flexuosum was the dominant filamentous alga on all dates except 18 January 1990. It formed a very dense canopy of entangled filaments that covered the $H$. wrightii leaves but these were by far most abundant around the blade edges. This alga frequently supported a dense covering of epiphytic diatoms either attached directly to the filaments (e.g. Rhopalodia spp., Tabularia spp.) or as chains of cells entangled

Table 1. Non-diatom filamentous algae epiphytic on Halodule wrightii and a relative indication of their abundance on each collection date. +: rare; ++: common; +++ : dominant

\begin{tabular}{|c|c|c|c|c|c|c|c|c|c|c|}
\hline & \multicolumn{5}{|c|}{1989} & \multicolumn{5}{|c|}{1990} \\
\hline & 29 Jun & $20 \mathrm{Jul}$ & 15 Aug & $15 \mathrm{Sep}$ & $27 \mathrm{Oct}$ & $18 \mathrm{Jan}$ & $16 \mathrm{Feb}$ & 15 May & 5 Jun & 25 Jun \\
\hline $\begin{array}{l}\text { Acrochaetium flexuosum } \\
\text { Vickers }\end{array}$ & +++ & +++ & +++ & +++ & ++ & & +++ & +++ & +++ & +++ \\
\hline Polysiphonia sp. & ++ & ++ & + & & & & & & + & + \\
\hline \multicolumn{11}{|l|}{ Hummia onusta (Kütz) Fiore } \\
\hline Gametophyte & & & & & ++ & & & & & \\
\hline Sporophyte & & & & & & +++ & ++ & & & \\
\hline $\begin{array}{l}\text { Giffordia mutchelliae } \\
\text { (Harvey) Hamel }\end{array}$ & & & & & & & + & + & + & + \\
\hline
\end{tabular}


amongst its filaments (e.g. Grammatophora spp., Fragilaria, spp.). Edwards (1976) recorded A. flexuosum as a common year-round epiphyte in Aransas Bay, Texas. The red alga Polysiphonia sp. was present on $H$. wrightii in June and July, but it was much less abundant than Acrochaetium. Hummia onusta was the most abundant brown alga; its occurrence was restricted to late fall and winter. Humm (1964), Dawes (1974), Ballantine \& Humm (1975) and Edwards (1976) have all recorded the gametophytic phase of $H$. onusta as an abundant year-round epiphyte on $H$. wrightii and the sporophytic phase as abundant but only during winter and spring. Small populations of the brown alga Giffordia mitchelliae were observed from 16 February to 25 June 1990. The same 4 authors listed above also report this alga as a common epiphyte on seagrass leaves. The most common non-algal epiphytes on $H$. wrightii blades were calcareous bryozoans, a hydroid, and a vorticellan type of protozoan. The hydroid was typically covered by Cocconeis spp. and the protozoan supported large numbers of the diatoms Licmophora spp. and Tabularia spp.

Along with the filamentous red alga Acrochaetium flexuosum, the epiphytic flora of Halodule wrightii was dominated by araphid and raphid pennate diatoms. Diatoms utilized all available surfaces for attachment; they were abundant over the entire leaf blade, on the red and brown filamentous algal epiphytes, and on the hydroid and protozoan epiphytes. A total of 61 diatom taxa representing 19 genera were encountered in the samples (see Sullivan et al. 1991 for a complete listing). The 12 most abundant diatom taxa and their relative abundances are listed in Table 2; collectively, these 12 taxa accounted for $8485(94.3 \%)$ of the 9000 valves counted. The 3 most abundant epiphytic diatoms were Fragilaria hyalina, Amphora tenuissima, and Mastogloia pumila, accounting for slightly more than 1 out of every 2 valves counted in the combined samples. Other taxa with total valve counts $\geq 600$ were Rhopalodia acuminata, Berkeleya hyalina, and Cocconeis scutellum. Collectively, these 6 taxa accounted for 3 out of every 4 valves counted. Most of the dominant diatom taxa exhibited a moderately to highly pronounced seasonality. A comparison of the dominant epiphytic diatom taxa of the present study with those recorded by Sullivan (1979) on $H$. wrightii in the same locality off Horn Island indicates a surprisingly high degree of similarity in the 2 floras separated in time by more than a decade.

With the exception of 2 collections, diatoms completely dominated the phytoplankton populations overlying the Halodule wrightii beds. Although many genera were encountered, the following were most abundant: Chaetoceros, Rhizosolenia, Thalassiosira, Coscinodiscus, Hemiaulus, Guinardia, and Leptocylindrus. Benthic forms were sometimes observed, but their numbers were small; they were members of the sediment flora rather than the epiphytic one. Dinoflagellates dominated the phytoplankton on 15 September 1989 and 5 June 1990; otherwise, their numbers were small. Virtually all cells belonged to the dinoflagellate genera Prorocentrum and Ceratium. The virtual absence of other flagellate groups may have been due to the net size $(28 \mu \mathrm{m})$ or disintegration during the 1 or $2 \mathrm{~d}$ period from collection to microscopic observation, or may reflect the true nature of the flora.

Table 2. Seasonality of the 12 most abundant diatoms epiphytic on Halodule wrightii. (\% of total valve count for each time period and all combined samples). Mean $H^{\prime}$ (Shannon-Wiener informational index) and $S$ (number of taxa) values also shown

\begin{tabular}{|c|c|c|c|c|}
\hline Diatom taxon & 29 Jun-27 Oct 1989 & 18 Jan-16 Feb 1990 & 15 May-25 Jun 1990 & Total \\
\hline Amphora tenuissima & 23.8 & 1.7 & 18.7 & 17.9 \\
\hline Berkeleya hyalina & 0.0 & 35.3 & 1.9 & 7.6 \\
\hline $\begin{array}{l}\text { Cocconeis placentula } \\
\text { var. euglypta }\end{array}$ & 3.9 & 0.2 & 7.4 & 4.2 \\
\hline C. scutellum & 4.2 & 0.6 & 14.9 & 6.7 \\
\hline Fragilaria hyalina & 29.7 & 12.9 & 16.2 & 22.3 \\
\hline Grammatophora oceanica & 2.8 & 4.4 & 3.6 & 3.3 \\
\hline Mastogloia pumila & 2.4 & 29.2 & 19.9 & 13.0 \\
\hline Navicula duerrenbergiana & 1.6 & 0.4 & 0.5 & 1.0 \\
\hline Nav. perminuta & 1.2 & 0.3 & 2.1 & 1.3 \\
\hline Nitzschia fontifuga & 10.1 & 0.1 & 1.5 & 5.5 \\
\hline Rhopalodia acuminata & 11.6 & 0.3 & 7.7 & 8.1 \\
\hline Tabularia fasciculata & 2.2 & 10.4 & 0.2 & 3.3 \\
\hline$H^{\prime}$ (bits ind.-1) & 2.562 & 2.302 & 2.779 & 2.575 \\
\hline$S$ (no. taxa sample ${ }^{-1}$ ) & 17.6 & 14.0 & 17.2 & 16.8 \\
\hline
\end{tabular}




\section{Epiphytic algal production}

Hourly primary production in individual beds ranged from $33 \mathrm{mg} \mathrm{C} \mathrm{m} \mathrm{m}^{-2} \mathrm{~h}^{-1}$ on 5 June 1990 to $1143 \mathrm{mg} \mathrm{C} \mathrm{m}^{-2} \mathrm{~h}^{-1}$ on 1 June 1989 , with a grand mean for the entire study of $302 \pm 300 \mathrm{mg} \mathrm{C} \mathrm{m}^{-2} \mathrm{~h}^{-1}$ (Fig. 2). Large differences in epiphytic production among the 3 beds occurred on 29 June and 20 July 1989, and 16 February 1990, with productivity values of $479.2 \pm$ $216.1,354.5 \pm 149.1$ and $292.4 \pm 236.2 \mathrm{mg} \mathrm{C} \mathrm{m}^{-2} \mathrm{~h}^{-1}$ respectively. This variation may represent higher values being associated with newer epiphytic algal growth and lower ones with senescent populations resulting from differential grazing pressures, as blades of similar lengths and thus similar ages were selected for incubations. Variability on all other sampling dates was relatively low, with an average SD of $42.2 \mathrm{mg}$ $\mathrm{C} \mathrm{m}^{-2} \mathrm{~h}^{-1}$ (range 6.5 to 92.9).

Stepwise multiple regression employing hourly production on an areal basis $\left(\mathrm{m}^{-2}\right)$ as the dependent variable yielded an $\mathrm{R}^{2}$ of only 0.15 ; a single variable with a positive partial regression coefficient (light energy) entered the regression equation (Table 3 ).

\section{Seagrass blade production}

Lowest seagrass blade production in individual beds was observed in January $\left(0.9 \mathrm{mg} \mathrm{C} \mathrm{m}^{-2} \mathrm{~h}^{-1}\right)$, while the highest value ( $149 \mathrm{mg} \mathrm{C} \mathrm{m}^{-2} \mathrm{~h}^{-1}$ ) was observed in May. The mean for the entire study was $60 \pm 39 \mathrm{mg} C$ $\mathrm{m}^{-2} \mathrm{~h}^{-1}$. Variation amongst beds was generally low, with the exception of 15 May 1990, when production values averaged $132.5 \pm 28.2 \mathrm{mg} \mathrm{C} \mathrm{m}{ }^{-2} \mathrm{~h}^{-1}$. On this

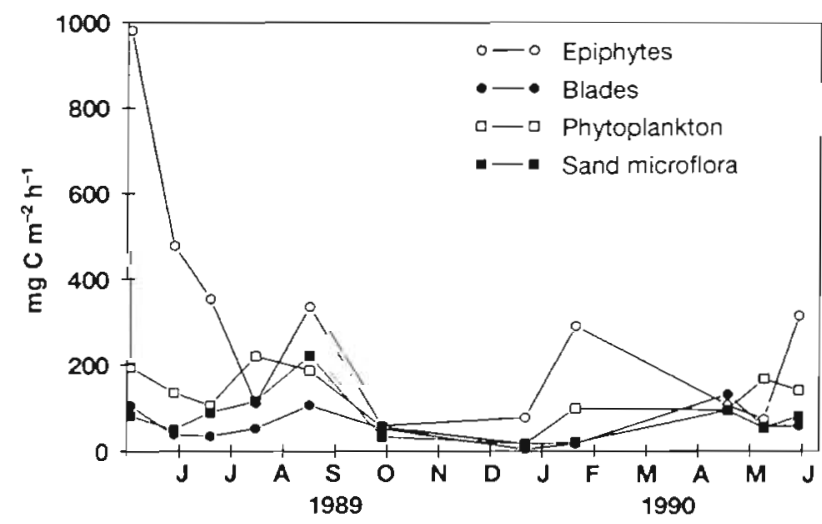

Fig. 2. Average hourly primary production values for all 4 autotrophic components in the Halodule wrightii bed system at the Horn Island study site from 1 June 1989 to 25 June 1990. Phytoplankton values are in $\mathrm{mg} \mathrm{C} \mathrm{m} \mathrm{m}^{-3} \mathrm{~h}^{-1}(\mathrm{n}=9)$; remaining components are in $\mathrm{mg} \mathrm{C} \mathrm{m} \mathrm{Cm}^{-2} \mathrm{~h}^{-1}(n=15)$. Data for sand microflora productivity are taken from Daehnick et al. (1992)
Table 3. Partial and cumulative $\mathrm{R}^{2}$ values and $F$-values for each variable (and the sign of its regression coefficient) entering the stepwise multiple regression models employing hourly production on an areal (mg $\mathrm{C} \mathrm{m}^{-2} \mathrm{~h}^{-1}$ ) and on a biomass basis ( $\mathrm{mg} \mathrm{C} \mathrm{g}^{-1}$ dry $\mathrm{wt}^{-1}$ ) as the dependent variable

\begin{tabular}{|ccccc|}
\hline Variable & Sign & $\begin{array}{c}\text { Partial } \\
\mathrm{R}^{2}\end{array}$ & $\begin{array}{c}\text { Model } \\
\mathrm{R}^{2}\end{array}$ & Prob $>F$ \\
\hline $\begin{array}{c}\text { Areal basis } \\
\text { Epiphytic algae }\end{array}$ & & & & \\
$\begin{array}{c}\text { PAR } \\
\text { Seagrass blades }\end{array}$ & $(+)$ & 0.15 & 0.15 & 0.0282 \\
PAR & $(+)$ & 0.53 & 0.53 & 0.0001 \\
BLADES & $(+)$ & 0.15 & 0.68 & 0.0007 \\
TIDE & $(-)$ & 0.07 & 0.75 & 0.0072 \\
TEMP & $(+)$ & 0.05 & 0.80 & 0.0144 \\
$\begin{array}{c}\text { Phytoplankton } \\
\text { TEMP }\end{array}$ & $(+)$ & 0.66 & 0.66 & 0.0001 \\
$\begin{array}{c}\text { Biomass basis } \\
\text { Epiphytic algae } \\
\text { BLADES }\end{array}$ & & & & \\
$\begin{array}{c}\text { Seagrass blades } \\
\text { PAR }\end{array}$ & & & & \\
TIDE & $(+)$ & 0.21 & 0.21 & 0.0149 \\
& & 0.54 & 0.54 & 0.0001 \\
& & 0.20 & 0.74 & 0.0003 \\
\hline
\end{tabular}

date, seagrass blade density was high in all beds; however, density differences between beds were also high. Standard deviations for the other study dates averaged $9.8 \mathrm{mg} \mathrm{C} \mathrm{m}^{-2} \mathrm{~h}^{-1}$.

Stepwise multiple regression identified light energy (PAR) as 'explaining' $53 \%$ of the observed variation in hourly blade production (Table 3 ). Other variables entering the regression equation were blade density, tidal range, and water temperature, which produced an overall $R^{2}$ of 0.80 . The sign of the partial regression coefficient for all variables except tidal range was positive.

\section{Biomass-based productivity estimates}

To avoid potential pitfalls inherent in areal-based productivity estimates, many researchers have expressed primary production rates for epiphytes and seagrass leaves on a dry weight basis (Morgan \& Kitting 1984, Jensen \& Gibson 1986). This allows a degree of compensation for changes in seagrass blade length and age and the degree of epiphytization of seagrass blades, and thus standardization, that is not possible when relying strictly on stem densities for areal estimates. Average intact seagrass blade biomass (seagrass blades with epiphytes) for the entire study was $108 \pm 37 \mathrm{~g}$ dry wt $\mathrm{m}^{-2}$, ranging from $42 \mathrm{~g} \mathrm{~m}^{-2}$ on 8 August 1989 to $166 \mathrm{~g} \mathrm{~m}^{-2}$ on 2 February 1990. Halodule wrightii blades and their associated epiphytes 


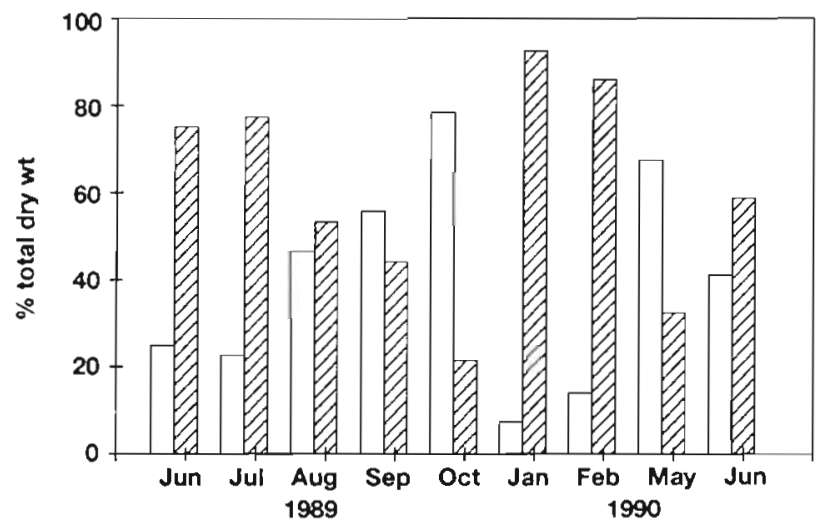

Fig. 3. Percent contribution of Halodule wrightii blades (open bars) and their associated epiphytes (hatched bars) to total dry weight $(n=6)$

often contributed strikingly different amounts of biomass over the course of the study (Fig. 3). Large fluctuations in water quality (primarily salinity and temperature) and grazing pressures associated with changing faunal assemblages appeared to be the major factors controlling degree of epiphytization. Under optimum growth conditions in Mississippi Sound, biomass values for $H$. wrightii blades are reported to average $138 \mathrm{~g}$ dry wt $\mathrm{m}^{-2}$ (Eleuterius 1987). Relative proportions of each component are a good indicator of degree of epiphytization. $H$. wrightii blades were most heavily epiphytized during January and February, with the contribution by epiphytes to total biomass exceeding $90 \%$ in January. Epiphyte coverage of the seagrass blades decreased during fall and spring months, followed by an increase in June (Fig. 3).

Seagrass blade production per $g$ dry weight of epiphyte-free Halodule wrightii blades is shown in Fig. 4. Monthly averages ranged from 4.2 to $38.0 \mathrm{mg} \mathrm{C}$

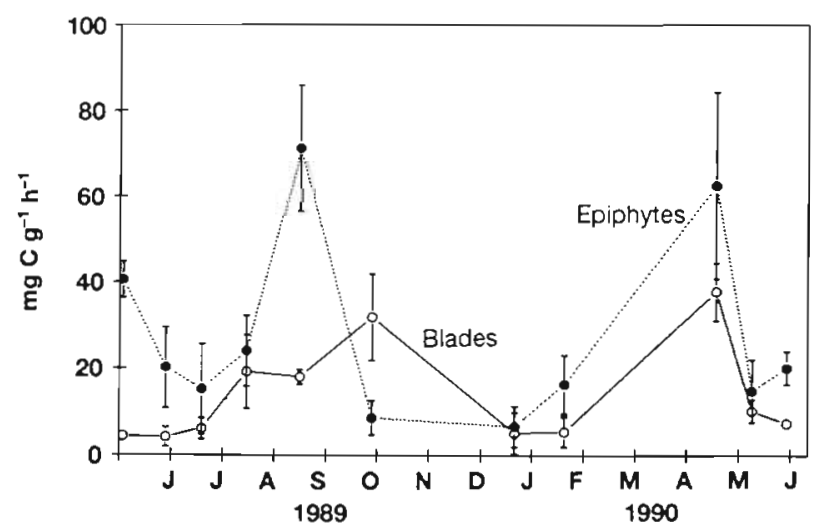

Fig. 4. Average weight-specific hourly primary production values ( $\mathrm{mg} \mathrm{C} \mathrm{g}^{-1} \mathrm{~h}^{-1}$ ) for seagrass blades (o) and epiphytes (•) at the Horn Island study site from 1 June 1989 to 25 June $1990(\mathrm{n}=15)$ $\mathrm{g}^{-1}$ dry wt h $\mathrm{h}^{-1}$, with a grand mean of $13.6 \pm 11.3 \mathrm{mg} \mathrm{C}$ $\mathrm{g}^{-1}$ dry $w \mathrm{t} \mathrm{h}^{-1}$. Epiphyte productivity rates ranged from 6.6 to $62.7 \mathrm{mg} \mathrm{C} \mathrm{g}^{-1}$ dry wt epiphytes $\mathrm{h}^{-1}$, with a grand mean of $27.4 \pm 20.6 \mathrm{mg} \mathrm{C} \mathrm{g}^{-1}$ dry wt epiphytes $\mathrm{h}^{-1}$. Fig. 4 also shows that epiphyte productivity exceeded that of the seagrass blades when based on biomass on all dates except 27 October 1989. Biomass-based rates were virtually equal on 18 January and 5 June 1990. These 3 dates represent occasions when hourly epiphyte and seagrass blade production were nearly identical on an areal basis (see Fig. 2).

Stepwise multiple regression identified light energy (PAR) and tidal range as potentially most important in 'explaining' observed variations in seagrass blade production based on biomass (Table 3). Blade density and water temperature, which entered the regression employing blade production on an areal basis as the dependent variable, did not enter the biomass-based model. However, $\mathrm{R}^{2}$ values for the biomass and areal models were similar, being 0.74 and 0.80 respectively. The stepwise multiple regression for epiphyte production based on epiphyte biomass (Table 3) showed that $21 \%$ of the variation could be 'explained' by variations in blade density, as would be expected for epiphytes. Blade densities per $100 \mathrm{~cm}^{2}$ quadrat ranged from 18 in January 1990 to 265 in May 1990, with an average of 115.9 blades quadrat ${ }^{-1}$. In the stepwise regression utilizing epiphyte production rates on an areal basis, only light energy entered the model and $\mathrm{R}^{2}$ was 0.15 (Table 3 ). Hence, there was only a small improvement in the biomassbased model over the areal-based model. This small improvement supports the idea that water quality and grazing may be more important than leaf age with respect to the degree of development of the epiphyte population.

\section{Phytoplankton production}

Observed phytoplankton production was lowest in January (16 mg $\mathrm{C} \mathrm{m} \mathrm{m}^{-2} \mathrm{~h}^{-1}$ ) and highest in August (231 $\mathrm{mg} \mathrm{C} \mathrm{m}^{-2} \mathrm{~h}^{-1}$ ) (Fig. 2). Mean phytoplankton hourly production for the entire study was $130 \pm 57 \mathrm{mg}$ $\mathrm{C} \mathrm{m}^{-2} \mathrm{~h}^{-1}$. Production over individual beds for a given date were generally in close agreement, with the greatest variation being observed on 25 June 1990 , when observed production was $141.9 \pm 37.4 \mathrm{mg} \mathrm{C}$ $\mathrm{m}^{-2} \mathrm{~h}^{-1}$. Standard deviation averaged $9.7 \mathrm{mg} \mathrm{C} \mathrm{m}^{-2} \mathrm{~h}^{-1}$ on all other study dates.

Stepwise multiple regression identified water temperature as the only independent variable potentially important in regulating phytoplankton production (Table 3). This variable accounted for $66 \%$ of the observed variation in phytoplankton production. 


\section{Annual production estimates}

An estimate of the annual production of each autotrophic component was made by first calculating a seasonally adjusted average hourly rate. To accomplish this, an approach that gave equal weight to each of the 12 months was employed. The 4 determinations made in June 1989 and June 1990 were averaged, and values for months during which no measurements were made were calculated by extrapolating between successive sampling dates. This resulted in hourly production values for each month, which were averaged to yield an unbiased hourly rate for each component over the entire study period. These hourly rates were multiplied by the average day length for the region (12 h), which were then multiplied by 365 days to yield annual estimates. Annual production rates $\left(\mathrm{g} \mathrm{C} \mathrm{m}^{-2}\right)$ were estimated as follows: epiphytic algae (905), phytoplankton (468), sand microflora (339) and Halodule wrightii (256). System production was dominated by the epiphytic algae on 7 of the 11 sampling dates (Fig. 2). Phytoplankton were the most productive component on 2 of the 4 dates when epiphytes were not the major producers (15 August 1989 and 5 June 1990); rates were essentially equal for all producers on the remaining 2 dates (27 October 1989 and 15 May 1990).

\section{DISCUSSION}

Epiphytic algae in Mississippi Sound were for the most part more productive than their counterparts in temperate, subtropical and tropical seagrass beds whereas the opposite was true for the seagrasses themselves. The annual primary production $\left(905 \mathrm{~g} \mathrm{C} \mathrm{m}^{-2}\right)$ of epiphytic algae measured in the present study is an order of magnitude higher than that measured in the studies of Penhale (1977), Borum \& Wium-Andersen (1980), and Borum et al. (1984), where annual rates of 50 to $70 \mathrm{~g} \mathrm{C} \mathrm{m}^{-2}$ were estimated. The only comparable values are those of Morgan \& Kitting (1984) for Halodule wrightii beds of Texas; average hourly epiphyte production was 115 and $229 \mathrm{mg} \mathrm{C} \mathrm{m} \mathrm{m}^{-2} \mathrm{~h}^{-1}$ in 2 different locations, which compare well with a seasonally adjusted hourly estimate of $206 \mathrm{mg} \mathrm{C} \mathrm{m}{ }^{-2} \mathrm{~h}^{-1}$ for the present study. $H$. wrightii blades in Mississippi Sound had an annual production rate of $256 \mathrm{~g} \mathrm{C} \mathrm{m}^{-2}$; this is greater than $69 \mathrm{~g} \mathrm{C} \mathrm{m}^{-2}$ for Zostera marina measured by Borum \& Wium-Andersen (1980) but less than annual estimates of 310 and $814 \mathrm{~g} \mathrm{C} \mathrm{m}^{-2}$ made for Z. marina by Penhale (1977) and Borum et al. (1984) respectively. Murray \& Wetzel (1987) measured the production rates of seagrass blades with intact epiphytes but stated that the latter contributed less that $7 \%$ of the total biomass. They reported gross annual rates of 707 and $867 \mathrm{~g} \mathrm{C} \mathrm{m}^{-2}$ for Ruppia maritima L. and $Z$. marina respectively. In the geographically closest study, Morgan \& Kitting (1984) recorded average hourly rates of 124 and $180 \mathrm{mg} \mathrm{C} \mathrm{m}^{-2} \mathrm{~h}^{-1}$ for $H$. wrightii blades, which are more than twice those (58 $\mathrm{mg} \mathrm{C} \mathrm{m}^{-2} \mathrm{~h}^{-1}$ ) of the present study.

Light energy was strongly correlated with Halodule wrightii production but only weakly correlated with that of the epiphytes (Table 3). Preliminary P-I work showed that the epiphytic algae saturated at light levels of $300 \mu \mathrm{E} \mathrm{m}^{-2} \mathrm{~s}^{-1}$ or less, whereas $H$. wrightii blades associated with those epiphytes saturated at light levels greater than $600 \mu \mathrm{E} \mathrm{m}^{-2} \mathrm{~s}^{-1}$. Thus, the large standing crops of an epiphytic assemblage dominated by small unicellular diatoms and uniserate filaments of the red alga Acrochaetium flexuosum may be well adapted for primary production in this often turbid environment. This may help to explain the high annual rate measured as well as a possible inhibition of $H$. wrightii production by the epiphytic algae due to their interception of available light, inorganic carbon, and other nutrients (see review by Sand-Jensen \& Borum 1991).

Because of differences in methodology employed by various investigators, absolute comparisons of the performance of different seagrass species and their attached epiphytes are somewhat tenuous. We have therefore taken an approach of comparing relative performances of selected autotrophic components and include these in Table 4. A similar approach was used for comparison of sand microflora production in Daehnick et al. (1992). The highest contribution of epiphytic algae to combined seagrass blade + epiphyte production has been found in the present study. Although the range in this productivity index was large (6 to $78 \%$ ). using this approach, 5 of the 9 studies listed in Table 4 indicate that epiphytic algae could have been responsible for at least half of the combined production. Therefore, epiphytic algae represent an extremely important production component in many seagrass beds of the world, in some cases being more productive than their macroscopic seagrass hosts. While such documentation does of course exist in the literature, we believe that the production of organic matter by epiphytic algae is a worldwide phenomenon not sufficiently appreciated by some researchers.

Epiphytic algae may also make important contributions to combined seagrass blade + epiphyte biomass (Table 4). The highest values have been recorded for epiphytes of Halodule wrightii in Texas (Morgan \& Kitting 1984) and in our study in Mississippi Sound. The green color of the $H$. wrightii leaves in the present study was virtually obscured by the dense covering of epiphytic algae on the majority of sampling dates. Epiphytes accounted for 70 to $90 \%$ of total biomass on 
Table 4. Percent contribution of epiphytic algae to combined seagrass blade + epiphyte production and biomass. ND: not determined

\begin{tabular}{|c|c|c|c|c|}
\hline Production & Biomass & Seagrass & Location & Source \\
\hline 18 & 24 & Zostera marina & North Carolina, USA & Penhale (1977) \\
\hline 50 & 36 & Zostera marina & Denmark & Borum \& Wium-Andersen $(1980)$ \\
\hline 6 & ND & $\begin{array}{l}\text { Halodule wrightii } \\
\text { Syringodium filiforme } \\
\text { Thalassia testudinum }\end{array}$ & Florida, USA & Heffernan \& Gibson (1983) \\
\hline ND & $29-42$ & Thalassia hemprichii & Papua New Guinea & Heijs (1984) \\
\hline 8 & $1-5^{\mathrm{d}}$ & Zostera marina & Denmark & Borum et al. (1984) \\
\hline $48-56$ & $\begin{array}{l}19-68 \\
30-67\end{array}$ & Halodule wrightii & Texas, USA & Morgan \& Kitting (1984) \\
\hline $27-50$ & ND & Zostera marina & Massachusetts, USA & Mazzella \& Alberte (1986) \\
\hline 56 & ND & $\begin{array}{l}\text { Halodule wrightii } \\
\text { Syringodium filiforme } \\
\text { Thalassia testudinum }\end{array}$ & Florida, USA; Bahamas & Jensen \& Gibson (1986) \\
\hline 36 & ND & $\begin{array}{l}\text { Halodule uninervis } \\
\text { Thalassia hemprichii }\end{array}$ & Indonesia & Lindeboom \& Sandee (1989) \\
\hline 78 & 59 & Halodule wrightii & Mississippi Sound, USA & Present study \\
\hline
\end{tabular}

4 of these dates (see Fig, 3). As is the case for primary production, biomass of epiphytic algae in the world's seagrass beds may be significant and should be separated from that of the blades in such cases.

Among the benthic autotrophs in seagrass beds of Mississippi Sound, the epiphytic algae were the dominant primary producers, accounting for $60 \%$ of total benthic primary production. Halodule wrightii blades were least productive $(17 \%)$, with the sand microflora contributing slightly more than the blades (23\%). Nearly $85 \%$ of all benthic primary production was therefore attributable to benthic microalgae. In tropical seagrass beds of northern Australia, Pollard \& Moriarty (1991) found that benthic algae (macroalgae, epiphytes and sand microflora) were the dominant producers, accounting for 40 to $90 \%$ of total benthic primary production. Jensen \& Gibson (1986) observed that epiphytic algae and sand microflora were responsible for 46 and $21 \%$ of total benthic primary production respectively, for a combined sum of $67 \%$.

Total annual benthic primary production in the present study was $1500 \mathrm{~g} \mathrm{C} \mathrm{m}^{-2}$ (Table 5). Adding the contribution of phytoplankton (468 $\mathrm{g} \mathrm{C} \mathrm{m}^{-2}$ ) yields a value of $1968 \mathrm{~g} \mathrm{C} \mathrm{m}^{-2}$ for total annual system primary production. Epiphytic algae were the largest contributors $(46 \%)$ and Halodule wrightii blades $(13 \%)$ the smallest contributors to total system production. Table 5 compares benthic and total primary production and

Table 5. Annual primary production estimates $\left(\mathrm{g} \mathrm{C} \mathrm{m}^{-2}\right)$ in seagrass bed systems. Benthic $=$ seagrasses + epiphytes + sand microflora total $=$ benthic + phytoplankton; $\mathrm{B} / \mathrm{T}=$ ratio of benthic to total system production

\begin{tabular}{|c|c|c|c|c|c|}
\hline Benthic & Total & $\mathrm{B} / \mathrm{T}$ & Seagrass & Location & Source \\
\hline 432 & 813 & 0.53 & Thalassia testudinum & Boca Ciega Bay, Florida & Pomeroy $(1960)$ \\
\hline 158 & 171 & 0.92 & $\begin{array}{l}\text { Halodule wrightii } \\
\text { Syringodium filiforme } \\
\text { Thalassia testudinum }\end{array}$ & Florida, USA & Heffernan \& Gibson (1983) \\
\hline 330 & 779 & 0.42 & $\begin{array}{l}\text { Halodule wrightii } \\
\text { Syringodium filiforme } \\
\text { Thalassia testudinum }\end{array}$ & Tampa Bay, Florida, USA & Jensen \& Gibson (1986) \\
\hline 123 & 441 & 0.28 & $\begin{array}{l}\text { Halodule wrightii } \\
\text { Syringodium filiforme } \\
\text { Thalassia testudinum }\end{array}$ & Indian River, Florida, USA & Jensen \& Gibson (1986) \\
\hline 813 & 1100 & 0.74 & Ruppia maritima & Virginia, USA & Murray \& Wetzel (1987) \\
\hline 1092 & 1580 & 0.69 & Zostera marina & Virginia, USA & Murray \& Wetzel (1987) \\
\hline 1500 & 1968 & 0.76 & Halodule wrightii & Mississippi Sound, USA & Present study \\
\hline
\end{tabular}


their ratio in different seagrass systems. The 3 studies carried out in Florida were based on a limited number of sampling dates (Pomeroy 1960, $n=4$; Heffernan \& Gibson 1983, $\mathrm{n}=2$; Jensen \& Gibson 1986, $\mathrm{n}=4$ ); however, these were spread more or less evenly throughout the year, and were thus extrapolated to annual values for purposes of comparison since few investigators have included all 4 autotrophic components in productivity determinations made concurrently in the same seagrass beds. Highest benthic and total system primary productions estimates have been recorded for Ruppia maritima and Zostera marina by Murray \& Wetzel (1987) and for $H$. wrightii beds in the present study (Table 5). Interestingly, the ratio of benthic to system primary production for these beds falls within a narrow range of 0.69 to 0.76 . Phytoplankton production was relatively more important in the other studies listed in Table 5 ( 47 to $72 \%$ of system production), except for that of Heffernan \& Gibson (1983) where phytoplankton production was extremely low and contributed only $8 \%$ of total system primary production.

Based on the relative contributions of the 4 autotrophic components within seagrass beds of Mississippi Sound, the epiphytic algal assemblage may be the primary food source within this community, as opposed to the seagrasses themselves. Research is currently underway to test this hypothesis.

Acknowledgements. Without the able assistance of William Demoran, Malcolm Hodges, and Joseph Jewell, successful completion of this research project would not have been possible. They are all thanked for their contributions to environmental data collection and for going beyond the call of duty to accommodate the many requirements of this type of research. This work is a result of research sponsored in part by the NOAA Office of Sea Grant, Department of Commerce under Grant \#NA89AA-D-SG016, the Mississippi-Alabama Sea Grant Consortium and Mississippi State University. The U.S. Government is authorized to produce and distribute reprints for governmental purposes not withstanding any copyright notation that may appear hereon.

\section{LITERATURE CITED}

Ballantine, D. Humm, H. J. (1975). Benthic algae of the Anclote Estuary. I. Epiphytes of seagrass leaves. Fla Sci 38: $150-162$

Borum, J., Kaas, H., Wium-Andersen, S. (1984). Biomass variation and autotrophic production of an epiphytemacrophyte community in a coastal Danish area: II Epiphyte species composition, biomass and production. Ophelia 23: 165-179

Borum, J., Wium-Andersen, S. (1980). Biomass and production of epiphytes on eelgrass (Zostera marina L.) in the Oresund, Denmark. Ophelia, Suppl. 1: 57-64

Dauby, P. (1989). The stable carbon isotope ratios in benthic food webs of the Gulf of Calvi, Corsica. Cont. Shelf Res. 9 : $181-195$
Dawes, C. J. (1974). Marine algae of the west coast of Florida. Univ. Miami Press, Miami

Daehnick, A. E., Sullivan, M. J., Moncreiff, C. A. (1992). Primary production of the sand microflora in seagrass beds of Mississippi Sound. Bot. Mar. 35: 131-139

Edwards, P. (1976). Illustrated guide to the seaweeds and sea grasses in the vicinity of Port Aransas, Texas. Univ. Texas Press, Austin

Eleuterius, L. N. (1987). Seagrass ecology along the coasts of Alabama, Louisiana, and Mississippi. In: Durako, M. J., Phillips, R. C., Lewis, R. R. (eds.) Proc. symp. subtropicaltropical seagrasses southeast United States. Florida Mar. Resources Publ. No. 42, Florida Dept Nat. Resources and Bur. Mar. Res., St. Petersburg, p. 11-24

Fry, B. $(1984) .{ }^{13} \mathrm{C} /{ }^{12} \mathrm{C}$ ratios and the trophic importance of algae in Florida Syringodium filiforme seagrass meadows. Mar. Biol. 79: 11-19

Fry, B., Lutes, R., Northam, M., Parker, P. L., Ogden, J. \{1982\}. A. ${ }^{13} \mathrm{C}^{12} \mathrm{C}$ comparison of food webs in Caribbean seagrass meadows and coral reefs. Aquat. Bot. 14: 389-398

Fry, B., Macko, S. A., Zieman, J. C. (1987). Review of stable isotopic investigations of food webs in seagrass meadows. In: Durako, M. J., Phillips, R. C., Lewis, R. R. (eds.) Proc. symp. subtropical-tropical seagrasses southeast United States. Florida Mar. Resources Publ. No. 42, Florida Dept. Nat. Resources and Bur. Mar Res., St. Petersburg, p. $117-138$

Gleason, D. F. (1986). Utilization of salt marsh plants by postlarval brown shrimp: carbon assimilation rates and food preferences. Mar. Ecol. Prog. Ser. 31: 151-158

Hamilton, S. K., Lewis, W. M. Jr, Sippel, S. J (1992). Energy sources for aquatic animals in the Orinoco River floodplain: evidence from stable isotopes. Oecologia 89: $324-330$

Heffernan, J. J., Gibson, R. A. (1983). A comparison of primary production rates in Indian River, Florida seagrass systems. Fla Sci. 46: 295-306

Humm, H. J. (1964). Epiphytes of the seagrass, Thalassia testudinum, in Florida. Bull. mar. Sci. Gulf Carib. 14: $306-341$

Heijs, F. M. L. (1984). Annual biomass and production of epiphytes in three monospecific seagrass communities of Thalassia hemprichii (Ehrenb.) Aschers. Aquat. Bot. 20: $195-218$

Jensen, P. R., Gibson, R. A. (1986). Primary production in three subtropical seagrass communities: a comparison of four autotrophic components. Fla Sci. 49: 129-141

Kitting, C. L. (1984). Selectivity by dense populations of small invertebrates foraging among seagrass blade surfaces. Estuaries 7: 276-288

Kitting, C. L., Fry, B., Morgan, M. D. (1984). Detection of inconspicuous epiphytic algae supporting food webs in seagrass meadows. Oecolgia 62: 145-149

Legendre, L., Demers, S., Yentsch, C. M., Yentsch, C. S, (1983). The ${ }^{14} \mathrm{C}$ method: patterns of dark $\mathrm{CO}_{2}$ fixation and DCMU correction to replace the dark bottle. Limnol. Oceanogr. 28: 996-1003

Lindeboom, H. J., Sandee, A. J. J. (1989). Production and consumption of tropical seagrass fields in eastern Indonesia measured with bell jars and microelectrodes. Neth. J. Sea Res. 23: $181-190$

Mazzella, L., Alberte, R. S. (1986). Light adaptation and the role of autotrophic epiphytes in primary production of the temperate seagrass, Zostera marina L. J. exp. mar. Biol. Ecol. 100: 165-180

Morgan, M. D., Kitting, C. L. (1984). Production and utilization of the seagrass Halodule wrightii and its attached 
epiphytes. Limnol. Oceanogr. 29: 1066-1076

Murray, L., Wetzel, R. L. (1987). Oxygen production and consumption associated with major autotrophic components in two temperate seagrass communities. Mar. Ecol. Prog. Ser. 38: 231-239

Nichols, P. D., Klumpp, D. W., Johns, R. B. (1985). A study of food chains in seagrass communities. III. Stable carbon isotope ratios. Aust. J. mar. Freshwat. Res. 36: 683-690

Penhale, P. A. (1977). Macrophyte-epiphyte biomass and productivity in an eelgrass (Zostera marina L.) community. J. exp. mar. Biol. Ecol. 26: 211-224

Peterson, B. J., Howarth, R. W. (1987). Sulfur, carbon, and nitrogen isotopes used to trace organic matter flow in the salt-marsh estuaries of Sapelo Island, Georgia. Limnol. Oceanogr. 32: 1195-1213.

Pollard, P. C., Moriarty, D. J. W. (1991). Organic carbon decomposition, primary and bacterial productivity, and sulphate reduction, in tropical seagrass beds of the Gulf of Carpentaria, Australia. Mar. Ecol. Prog. Ser. 69: 149-159

Pomeroy, L. R. (1960). Primary productivity of Boca Ciega Bay, Florida. Bull. mar. Sci. Gulf. Carib. 10; 1-10

Sand-Jensen, K., Borum, J. (1991). Interactions among phytoplankton, periphyton, and macrophytes in temperate freshwaters and estuaries. Aquat. Bot. 41: 137-175

This article was submitted to the editor
SAS Institute Inc. (1988). SAS/STAT user's guide. Release 6.03 edn. SAS Institute Inc, Cary, NC

Strickland, J. D. H., Parsons, T. R. (1972). A practical handbook of seawater analysis, 2 nd edn. Bull. Fish. Res. Bd Can. 167: 267-278

Sullivan, M. J. (1979). Epiphytic diatoms of three seagrass species in Mississippi Sound. Bull. mar. Sci. 29: $459-464$

Sullivan, M. J., Moncreiff, C. A. (1990). Edaphic algae are an important component of salt marsh food-webs: evidence from multiple stable isotope analyses. Mar. Ecol. Prog. Ser. 62: $149-159$

Sullivan, M. J., Moncreiff, C. A., Daehnick, A. E. (1991). Primary production dynamics of epiphytic algae in Mississippi seagrass beds. Mississippi-Alabama Sea Grant Consortium, Ocean Springs, Mississippi, Report No. MASGP-91-009, $95 \mathrm{pp}$.

Thursby, G. B., Davis, J. S. (1984). Species composition and relative abundance of attached diatoms and other algae in the coastal waters adjacent to Seahorse Key, Florida. Fla Sci. 47: 130-140

van Raalte, C. D., Stewart, W. C., Valiela, I., Carpenter, E. J. (1974). A ${ }^{14} \mathrm{C}$ technique for measuring algal productivity in salt marsh muds. Bot. Mar. 17: 186-188

Manuscript first received: January 21, 1992

Revised version accepted: August 28, 1992 